\title{
Concomitant Double Tumors of Myxopapillary Ependymoma Presented at Cauda Equina-Filum Terminale in Adult Patient
}

\author{
Ulaş Yener ${ }^{1}$, Mustafa Güdük', Murat Şakir Ekşi ${ }^{2}$, Murat Hamit Aytar ${ }^{3}$, Aydın Sav ${ }^{4}$ Serdar Özgen ${ }^{1}$ \\ ${ }^{I}$ Department of Neurosurgery, Acibadem University Faculty of Medicine, Istanbul, Turkey, \\ ${ }^{2}$ Department of Orthopedic Surgery-Spine Center, University of California at San Francisco, CA, USA, \\ ${ }^{3}$ Department of Neurosurgery, Acıbadem University Vocational School of Health Services, Istanbul, \\ ${ }^{4}$ Department of Pathology, Acrbadem University Faculty of Medicine, Istanbul, Turkey
}

A 32-year-old man presented with gradually increasing bilateral buttock pain. He had intermittent claudication. Multiple, homogenously enhanced intradural extramedullary lesions at L2-L3 and L5-S1 levels were observed on magnetic resonance imaging. The tumors were debulked and were removed in piecemeal pattern until they had completely been resected. Histopathological examination of the surgical specimens confirmed that both tumors were myxopapillary ependymomas (MPE). MPE presenting as concomitant double tumor at conus-cauda-filum level are very rare. This kind of presentation could not be directly considered as dissemination, since both tumors were in the site of classical origin of MPE. Ten cases of double spinal MPEs have been reported to date. Including the present case, analysis of the 11 patients revealed some facts. There is a male predominance, which is opposite to the ependymomas that are commonly observed in females. Median age at presentation is 15 years. Most pronounced symptom is low back pain that sometimes radiates to lower extremities. Surgical approach was aimed in all tumors, which could be succeeded in all tumors except one. Adjuvant radiation therapy was applied in 5 patients. No recurrences have been reported after surgery or surgery + radiotherapy regimens.

Key Words: Ependymoma $\cdot$ Surgery $\cdot$ Radiotherapy $\cdot$ Low back pain

\section{INTRODUCTION}

Glial cells are composed of astrocytes and ependymal cells. Astrocytes supply structural support of the central nervous system whereas ependymal cells line the ventricular system. Tumors arising from both cell lines compose most of the spinal intramedullary tumors. Myxopapillary ependymoma (MPE) is a subtype of ependymoma, which is exclusively observed at conus smedullaris, cauda equina, and filum terminale ${ }^{17)}$.

Concomitant double tumor presentation of MPE at conuscauda-filum level is very rare. To date, 10 cases have been presented $^{2,8-10,16,17,21)}$. Herein, we report a new case of MPE presented as double tumor in noncontiguous segments of lumbosacral spinal column. We discuss clinical, radiological, pathological aspects and treatment modalities of these tumors.

- Received: December 29, 2015 • Revised: January 28, 2016

- Accepted: January 29, 2016

Corresponding Author: Ulas Yener, MD

Department of Neurosurgery, Acibadem University Faculty of Medicine, Halkalı Merkez, Turgut Özal Blv No:16, 34303 Halkalı-Küçükçekmece, Istanbul, Turkey

Tel: +90-536-3488978, Fax: +90-212-4044180

E-mail: ulasyener@yahoo.com

@This is an open access article distributed under the terms of the Creative Commons Attribution Non-Commercial License (http://creativecommons.org/licenses/by-nc/4.0/) which permits unrestricted non-commercial use, distribution, and reproduction in any medium, provided the original work is properly cited.

\section{CASE REPORT}

A 32-year-old man presented with gradually increasing bilateral buttock pain for the last 3 months. He had intermittent claudication. At examination, neither motor nor sensory disturbances were observed. Deep tendon reflexes were normal. No history of infection or trauma was present. The plain radiographs did not reveal any abnormalities. Magnetic resonance imaging showed multiple intradural extramedullary lesions with homogenous enhancement at L2-L3 and L5-S1 levels (Fig. 1). Whole cranium and spine were searched for any other tumors, yet no other one could be observed except the ones we have already detected at the lumbosacral region. L2 and L5 laminectomy were performed at the same session. Both lesions were observed as rounded, soft and reddish-gray colored. The lesions were completely encapsulated by thin fibrous capsules with a well-delimitated cleavage plane. The tumors were removed in piecemeal pattern until they were completely resected under the surgical microscope. Following resection and hemostasis, the dura was repaired in watertight fashion. Postoperative imaging confirmed total resection of both lesions (Fig. 2). Histopathological examination of the surgical specimens confirmed that both lesions were MPEs (Fig. 3). No adjuvant therapies were performed. At 1-year follow-up his neurological status remained stable. 

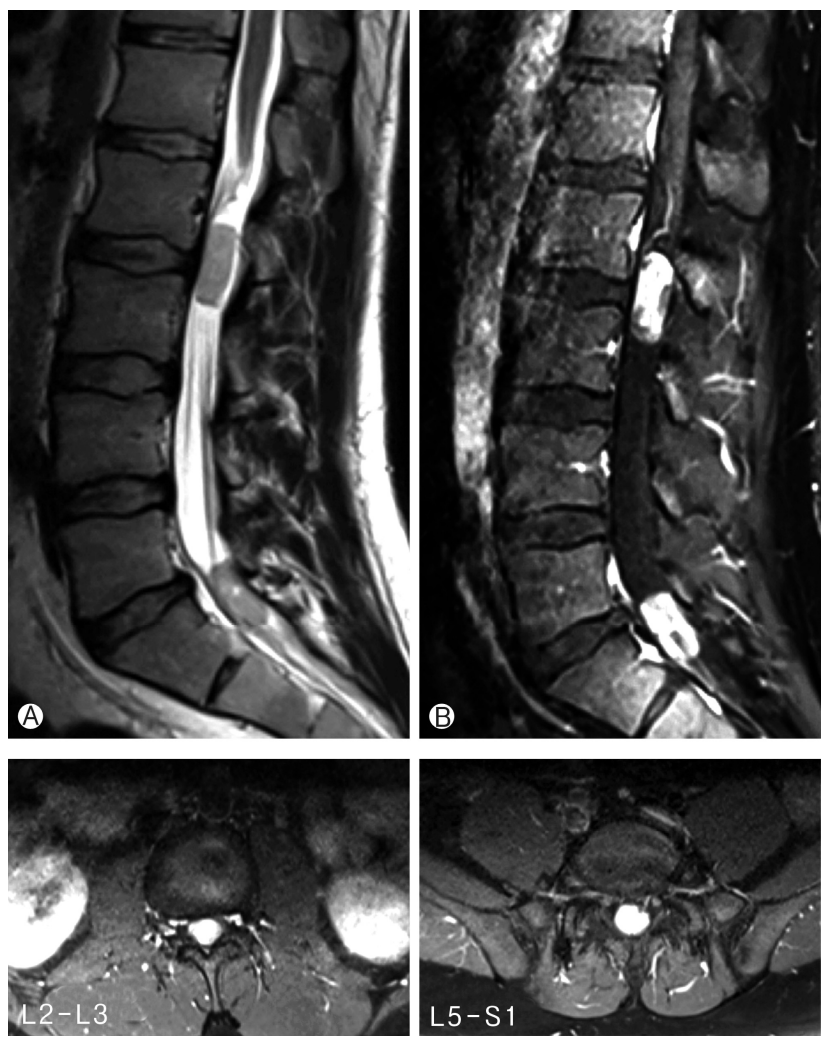

Fig. 1. One lesion at L2-L3 level and other lesion at L5-S1 level is observed through the tight filum terminale on T2-weighed magnetic resonance imaging scan (A). (B) Homogenous gadolinium enhancement is observed in both pathologies.

\section{DISCUSSION}

MPEs are World Health Organization grade I (low-grade) ependymomas originating mostly from the filum terminale or the terminal ventricle ${ }^{5,14,99}$. For this reason MPEs are detected as solitary tumors more commonly at conus-cauda-filum lev$\mathrm{els}^{5,19,21)}$. Intracranial, cervical and thoracic region lesions are considered as CSF dissemination of MPEs, yet reverse situations have also been reported ${ }^{21,25)}$. Tumor dissemination is basically caused by violation of tumor capsule of MPEs caused by piecemeal tumor removal, traumatic spinal tap, spinal trauma, spinal instrumentation, and tumor hemorrhage $4,11,15,18,20,21,23,27)$.

MPE is iso-intense on T1- and hyper-intense on T2-weighted MRI with heterogenous imaging properties on T2-weighted scans. These heterogeneities correspond to hemorrhages and calcifications present in the tumor ${ }^{3,12}$.

MPE is composed of cellular areas harboring rosettes and pseudorosettes intermingled with papillary regions, which have vascular cores in mucoid matrix ${ }^{14,19,21)}$. MPEs sometimes coexist with spinal dysraphisms ${ }^{1,724,26}$.

MPEs presenting as concomitant double tumors at conuscauda-filum level are very rare. This kind of presentation could

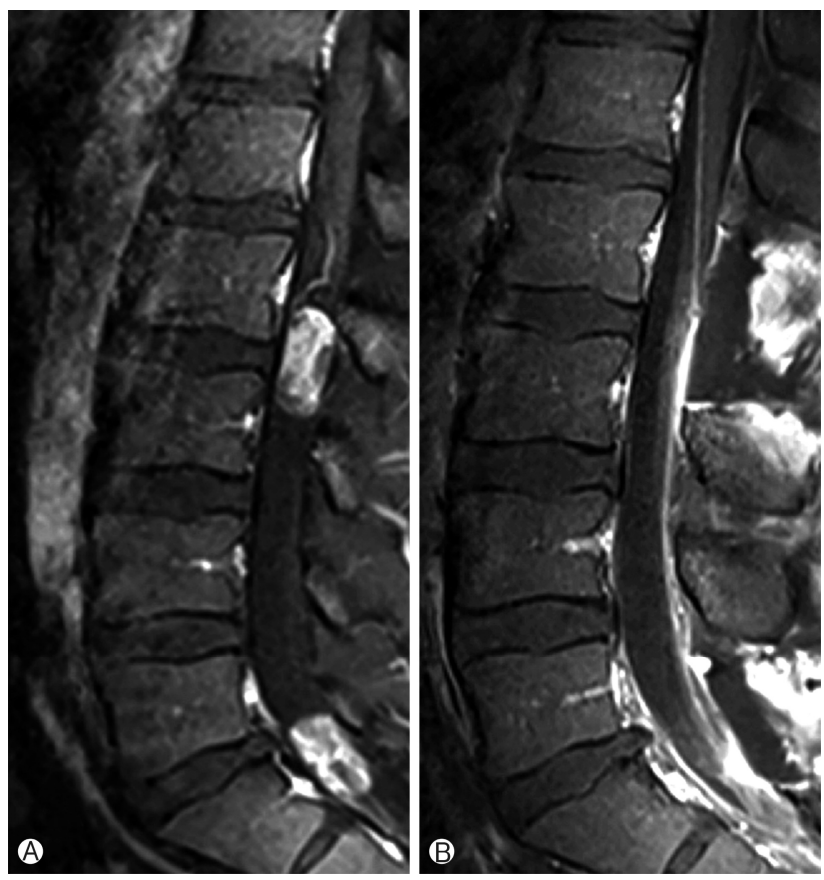

Fig. 2. Both lesions were resected totally: preoperative (A), and postoperative (B) contrast enhanced T1-weighted lumbar magnetic resonance imaging scans.

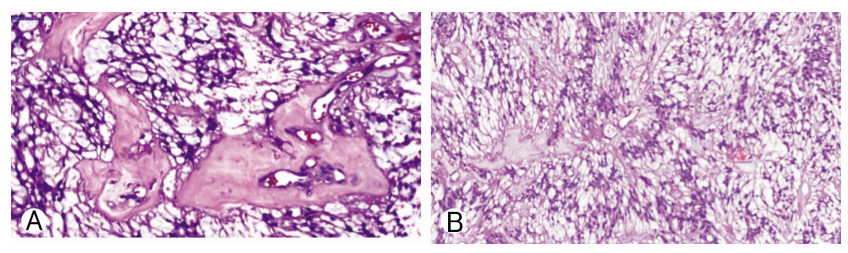

Fig. 3. (A) Hyalinized blood vessels surrounded by tumor cell processes with abundant myxoid material in matrix $(\mathrm{H} \& \mathrm{E}, \times 23.6)$. (B) Myxopapillary ependymoma demonstrating radial perivascular arrangement of tumor cell processes $(\mathrm{H} \& \mathrm{E}, \times 16.4)$.

not be directly considered as dissemination, since both tumors are in the site of classical origin of MPEs ${ }^{21)}$. Ten cases have been presented up to date (Table 1) 2, $8-10,16,17,21)^{\text {. Including the }}$ present case, analyses of the 11 patients have revealed some facts. There is a male predominance (male:female $=6: 1$; sex was not mentioned for 4 patients ${ }^{10}$ ), which is opposite to the ependymomas which are commonly observed in females? ${ }^{6}$. Median age at presentation is 15 years (range, 7-39 years; age was not mentioned for 4 patients ${ }^{10)}$ ). This depicts that concomitant double presentation of MPE is mostly observed in children and young adults. Most common symptom is low back pain, sometimes radiating to lower extremity(ies). Surgical approach was aimed in all tumors, which was successful in all tumors, except one. Adjuvant radiation therapy was performed in 5 patients. In the first patient, both tumors had been resected en bloc, yet MIB-1 index was high (9.1\%). Whole craniospinal radiotherapy was given to the patient ${ }^{2}$. 
Table 1. Double presentation of myxopapillary ependymomas of conus medullaris, cauda equine, and filum terminale

\begin{tabular}{|c|c|c|c|c|c|c|}
\hline Source & Age/sex & Presentation & Location & Treatment & Follow-up (yr) & Outcome \\
\hline $\begin{array}{l}\text { Gelabert-González } \\
\text { et al. }{ }^{8)}(2001)\end{array}$ & $15 / \mathrm{F}$ & $\begin{array}{l}\text { Low back and left lower } \\
\text { extremity pain }\end{array}$ & $\mathrm{L} 2-\mathrm{L} 3, \mathrm{~S} 3$ & Total resection of both lesions & 0.5 & No recurrence \\
\hline $\begin{array}{l}\text { Hallacq et al. }{ }^{9)} \\
(2003)\end{array}$ & $13 / \mathrm{M}$ & $\begin{array}{l}\text { Low back and bilateral } \\
\text { lower extremity pain }\end{array}$ & $\mathrm{L} 2-\mathrm{L} 3, \mathrm{~S} 2$ & Total resection of both lesions & 5 & $\mathrm{~N} / \mathrm{A}^{*}$ \\
\hline $\begin{array}{l}\text { Nakama et al. } \\
(2005)\end{array}$ & $7 / \mathrm{M}$ & Low back pain, dysuria & L1-L2, S2 & Total resection of both lesions & 1 & No recurrence \\
\hline $\begin{array}{l}\text { Andoh et al. } \\
\text { (2011) }\end{array}$ & 39/M & $\begin{array}{l}\text { Bilateral buttock pain, } \\
\text { intermittent claudication }\end{array}$ & $\begin{array}{l}\mathrm{L} 2-\mathrm{L} 3, \\
\mathrm{~L} 5-\mathrm{S} 1\end{array}$ & $\begin{array}{l}\text { Total resection of both lesions } \\
+ \text { adjuvant radiotherapy }\end{array}$ & 3.5 & No recurrence \\
\hline $\begin{array}{l}\text { McLaughlin } \\
\text { et al. }^{16)}(2011)\end{array}$ & $28 / \mathrm{M}$ & Low back pain & $\begin{array}{r}\mathrm{L} 3-\mathrm{L} 4, \\
\mathrm{~L} 5-\mathrm{S} 2\end{array}$ & $\begin{array}{l}\text { Total resection of one lesion, } \\
\text { subtotal resection of the other } \\
\text { one }+ \text { adjuvant radiotherapy } \\
\text { for the residual tumor }\end{array}$ & 0.9 & No recurrence \\
\hline $\begin{array}{l}\text { Salomão et al. } \\
\text { (2014) }\end{array}$ & $14 / \mathrm{M}$ & $\begin{array}{l}\text { Low back and bilateral } \\
\text { lower extremity pain }\end{array}$ & $\begin{array}{l}\mathrm{T} 12-\mathrm{L} 3, \\
\mathrm{~S} 1-\mathrm{S} 2\end{array}$ & $\begin{array}{l}\text { Total resection of both } \\
\text { lesions }\end{array}$ & 2 & No recurrence \\
\hline $\begin{array}{l}\text { Khalatbari et al. } \\
\text { (2015) }\end{array}$ & $\begin{array}{l}4 \text { Patients } \\
\text { (age and } \\
\text { sex, N/A) }\end{array}$ & $\begin{array}{l}\text { Low back pain (all pa- } \\
\text { tients), lower extremity } \\
\text { radiculopathy ( } 3 \text { patients), } \\
\text { urinary incontinence } \\
\text { (1 patient) }\end{array}$ & $\begin{array}{l}\text { N/A (3 pa- } \\
\text { tients had } \\
2 \text { lesions, } 1 \\
\text { patient had } \\
3 \text { lesions) }\end{array}$ & $\begin{array}{l}6 \text { Tumors removed en bloc, } \\
3 \text { lesions removed gross } \\
\text { totally in piecemeal fashion, } \\
\text { radiotherapy was applied to } \\
3 \text { patients }\end{array}$ & $6^{+}$ & No recurrence \\
\hline This case & $32 / \mathrm{M}$ & $\begin{array}{l}\text { Bilateral buttock pain, } \\
\text { neurologic claudication }\end{array}$ & $\begin{array}{l}\mathrm{L} 2-\mathrm{L} 3, \\
\mathrm{~L} 5-\mathrm{S} 1\end{array}$ & $\begin{array}{l}\text { Total resection of both } \\
\text { lesions }\end{array}$ & 1 & $\mathrm{~N} / \mathrm{A}^{*}$ \\
\hline
\end{tabular}

N/A, not available.

"Family or patient declined postoperative follow-up magnetic resonance imaging. ${ }^{+}$Average value.

In the second patient, the second tumor could be excised partially, and local radiotherapy was given to the residual tumor bed $^{16)}$. Khalatbari et al. ${ }^{10)}$ operated 4 patients (6 tumors were removed en bloc, 3 tumors were removed gross totally in piecemeal fashion) and gave adjuvant radiotherapy to 3 patients. Average follow-up time was 3.4 years without any recurrence in any case.

MPEs have 3.6 times shorter time to metastasis compared to other type of low-grade ependymomas. Dissemination is more commonly seen in young patients with ependymomas ${ }^{20)}$. So, it is not clear yet if concomitant double tumor presentation is due to two different primary tumors or dissemination one from the other one ${ }^{17)}$. The second lesions have mainly been observed at the lumbosacral junction, which might be due to drop metastasis from the rostral lesion ${ }^{2,8,9,16,17,21)}$.

MPEs histologically have low malignancy level. However, tumor dissemination is observed in 33\% of patients with MPE at 5-year follow-up ${ }^{20)}$. So, long-term follow-up should be conveyed in every patient with a diagnosis of MPE, even in cases with aggressive therapy ${ }^{13,23)}$. Good prognosis is expected in $70 \%$ of the patients with appropriate treatment without considering total resection as a must ${ }^{2,22,23)}$.

\section{CONCLUSION}

Concomitant double presentation of myxopapillary epen- dymoma is a rare entity with a good prognosis; however long term follow-up is necessary to observe tumor progression in a timely fashion.

\section{CONFLICT OF INTEREST}

No potential conflict of interest relevant to this article was reported.

\section{REFERENCES}

1. Adamson DC, Cummings TJ, Friedman AH: Myxopapillary ependymoma and fatty filum in an adult with tethered cord syndrome: a shared embryological lesion? Case report. Neurosurgery 57:E373, 2005

2. Andoh H, Kawaguchi Y, Seki S, Asanuma Y, Fukuoka J, Ishizawa S, et al: Multi-focal myxopapillary ependymoma in the lumbar and sacral regions requiring cranio-spinal radiation therapy: a case report. Asian Spine J 5:68-72, 2011

3. Bandopadhayay P, Silvera VM, Ciarlini PD, Malkin H, Bi WL, Bergthold G, et al: Myxopapillary ependymomas in children: imaging, treatment and outcomes. J Neurooncol [Epub ahead of print], 2015

4. Chan HS, Becker LE, Hoffman HJ, Humphreys RP, Hendrick EB, Fitz CR, et al: Myxopapillary ependymoma of the filum 
terminale and cauda equina in childhood: report of seven cases and review of the literature. Neurosurgery 14:204-210, 1984

5. Choi BH, Kim RC, Suzuki M, Choe W: The ventriculus terminalis and filum terminale of the human spinal cord. Hum Pathol 23:916-920, 1992

6. Duffau H, Gazzaz M, Kujas M, Fohanno D: Primary intradural extramedullary ependymoma: case report and review of the literature. Spine (Phila Pa 1976) 25:1993-1995, 2000

7. Gallia GL, Burger PC, Suk I, Bagley CA, Wolinsky JP, Garonzik IM, et al: Concomitant conus medullaris ependymoma and filum terminale lipoma: case report. Neurosurgery 58:E1214, 2006

8. Gelabert-González M, Prieto-González A, Abdulkader-Nallib I, Cutrín-Prieto J: Double ependymoma of the filum terminale. Childs Nerv Syst 17:106-108, 2001

9. Hallacq P, Labrousse F, Streichenberger N, Lisii D, Fischer G: Bifocal myxopapillary ependymoma of the terminal filum: the end of a spectrum? Case report. J Neurosurg 98(3 Suppl):288289, 2003

10. Khalatbari MR, Hamidi M, Moharamzad Y: Primary multi-focal myxopapillary ependymoma of the filum terminale. J Neurosurg Sci [Epub ahead of print], 2015

11. Khalatbari MR, Jalaeikhoo H, Hamidi M, Moharamzad Y: Craniospinal dissemination of filum myxopapillary ependymoma following spinal trauma: case report and literature review. Childs Nerv Syst 29:149-152, 2013

12. Klekamp J: Spinal ependymomas. Part 2: Ependymomas of the filum terminale. Neurosurg Focus 39:E7, 2015

13. Landriel F, Ajler P, Tedesco N, Bendersky D, Vecchi E: Multicentric extramedullary myxopapillary ependymomas: Two case reports and literature review. Surg Neurol Int 3:102, 2012

14. Louis DN, Ohgaki H, Wiestler OD, Cavenee WK, Burger PC, Jouvet A, et al: The $2007 \mathrm{WHO}$ classification of tumours of the central nervous system. Acta Neuropathol 114:97-109, 2007

15. Martinez-Perez R, Hernandez-Lain A, Paredes I, Munarriz PM, Castaño-Leon AM, Lagares A: Acute neurological deterioration as a result of two synchronous hemorrhagic spinal ependymomas. Surg Neurol Int 3:33, 2012

16. McLaughlin N, Guiot MC, Jacques L: Double myxopapillary ependymomas of the filum terminale. Can J Neurol Sci 38:151154, 2011

17. Nakama S, Higashi T, Kimura A, Yamamuro K, Kikkawa I, Hoshino Y: Double myxopapillary ependymoma of the cauda equina. J Orthop Sci 10:543-545, 2005

18. Plans G, Brell M, Cabiol J, Villá S, Torres A, Acebes JJ: Intracranial retrograde dissemination in filum terminale myxopapillary ependymomas. Acta Neurochir (Wien) 148:343-346, 2006

19. Rasmussen TB, Kernohan JW, Adson AW: pathologic classification, with surgical consideration, of intraspinal tumors. Ann Surg 111:513-530, 1940

20. Rezai AR, Woo HH, Lee M, Cohen H, Zagzag D, Epstein FJ: Disseminated ependymomas of the central nervous system. J Neurosurg 85:618-624, 1996

21. Salomão JF, de Andrade CV, Bellas AR, Cervante TP: The nature of double concomitant myxopapillary ependymoma: report of a case. Childs Nerv Syst 30:527-530, 2014

22. Schweitzer JS, Batzdorf U: Ependymoma of the cauda equina region: diagnosis, treatment, and outcome in 15 patients. Neurosurgery 30:202-207, 1992

23. Sonneland PR, Scheithauer BW, Onofrio BM: Myxopapillary ependymoma: a clinicopathologic and immunocytochemical study of 77 cases. Cancer 56:883-893, 1985

24. Tubbs RS, Kelly DR, Mroczek-Musulman EC, Braune K, Reddy A, Georgeson K, et al: Dwarfism, occult spinal dysraphism, and presacral myxopapillary ependymoma with an epidermoid cyst in a child. Acta Neurochir (Wien) 147:299-302, 2005

25. Wang M, Wang H, Zhou Y, Zhan R, Wan S: Myxopapillary ependymoma in the third ventricle area and sacral canal: dropped or retrograde metastasis? Neurol Med Chir (Tokyo) 53: 237-241, 2013

26. Wolf NI, Harting I, Hartmann M, Aschoff A, Sommer C, Rating $\mathrm{D}$, et al: Combination of caudal myxopapillary ependymoma and dermal sinus: a single shared embryologic lesion? Dev Med Child Neurol 45:568-570, 2003

27. Yücesoy K, Ozer E, Koyuncuoglu M: Parenchymal brain metastasis of a spinal myxopapillary ependymoma after extradural manipulation. Acta Neurochir (Wien) 143:1071-1072, 2001 